\title{
Land expropriation model in South Africa: A consequent impact on food security
}

\author{
Malemela Angelina Mamabolo \\ University of Limpopo, South Africa \\ Mokoko Piet Sebola \\ University of South Africa, South Africa
}

\section{Keywords}

Economic Activities, Food Security, Land Expropriation, Land Redistribution

\begin{abstract}
The paper seeks to evaluate the land expropriation model and its effect on food security. Since the announcement by President Cyril Ramaphosa two years ago about land expropriation without compensation, the concern about how that will be implemented topped high in both political and academic debates. South Africa's land issue has been topical for many decades and with little progress achieved in resolving the identified problem. This paper is conceptual in approach, and it uses literature to argue that land expropriation without compensation will threaten food security in South Africa. The paper concludes that land expropriation without compensation that will not consider threat to food security will not achieve intended justice for the people it intends to serve in the country.
\end{abstract}

\section{Introduction}

Since the announcement of land expropriation without compensation in South Africa by President Cyril Ramaphosa two years ago, many debates and questions rose about implementation challenges facing such proposal. While others argue about pieces of legislation in place to fairly regulate that, others are seriously concerned about whose land to expropriate, which land is going to be affected and what will happen if the country expropriate land without compensation. Land in South Africa is owned invariably so, such as by the state, private individuals, companies and different trusts. Hence, the South African citizens are much concerned about who 's land will be expropriated when that time come. Notably, the idea on land expropriation without compensation was accepted and supported by different political parties such as the African National Congress (ANC), Economic Freedom Fighters (EFF) apart from other opposition parties which were aligned to white capitalists' class. Oppositions of the idea are concerned about the state of corruption in the country and argue that even with the expropriation which can constitutionally take effect, only those who are politically connected will enjoy benefits associated with expropriation while the poor will continue to suffer (Branson, 2016; Maimane, 2018). Access to land has been identified as an action that can reduce the level of hunger and increase access to food security in the country. That is, food security can only be visible when all citizens have access to economic resources such as land that will assist them to create economic activities that promote their standard of living. Land expropriation in South Africa has been construed to be more about government correcting the imbalance of the past with little attention on the political and economic consequences thereof (Cousins, 2018). Since the announcement of land expropriation without compensation in South Africa farmers started experiencing land problems such as illegal land occupation.

On the other hand, more political debates are concentrated on the way the process of land expropriation is going to be implemented. In the contrary, Stofberg (2018) asserts that the issue of land expropriation must be seen as a mere marketing tool for election. Indeed, the matter was prominent before the elections, and it took a quite stand after the 2019 general elections. The reality is that the South African Constitution does make provision for expropriation without compensation (Crosby, n.d) on public interests. Considering that the country has different portions of land owned by the state, private individuals, different companies and trust, the question is which land is targeted for such expropriation without compensation. Evidently, the Land Audit Report (2017) indicated that 82\% of land in the country is owned by private landowners as compared to those owned by other sectors of the economy. Arguably, the government's decision to expropriate land without compensation will undoubtedly, like in other 
African countries such as Zimbabwe, lead to famine and much greater poverty across the society. Despite all the failure of land reform models such as farm management model, strategic partnership model, the equitable share model, Land Redistribution for Agricultural Development (LRAD), Proactive Land Acquisition Strategy (PLAS), the Department of Rural Development and Land Reform Recapitalisation and Development Programme (RADP) and the willing buyer willing seller model, Kilian (2018) asserts that land expropriation model will strengthen land redistribution.

\section{Land redistribution and expropriation in south africa}

Land redistribution in the country has been argued to be moving very slow (Bennett, 2013; Sebola \& Tsheola, 2014; Khoza, 2016) and despite political noises made the status quo remain unchanged. According to the Department of Rural Development and Land Reform (2014), 30\% of land should have been redistributed by 2014 , but to date, however, only $8 \%$ has been redistributed. Just when the country is still working towards correcting the imbalance of the past by redistributing land to the disadvantaged communities, then the land issue gained a new focus on "Land Expropriation". Accordingly, land expropriation refers to land that is taken by the state and redistributed fairly back to the dispossessed black citizens (Head, 2018). Seemingly, the government announced land expropriation without compensation with the intention to drive land reform (The Institute of Race Relations, 2018). However, it is still not known as to whether through expropriation the government will be able to distribute land fairly without problems. In as much as land redistribution was never enough for the government to successfully distribute land to the African communities, the question is will expropriation be enough. Clearly the expropriation of land without compensation is the government's new agenda and it is made clear in the agenda that the approach must be done in a manner that is fair, sustainable and strengthen the economy (Bosshoff, Sihlobo \& Ntombela, 2018).

The government of South Africa has assured that the expropriation of land without compensation will be done in a manner that ensures food security, increases agricultural production and improves economic growth. It is therefore evident that the government is on a mission to strengthen land reform, however little has been recorded of economic viability of the redistributed land through land reform programmes. As Sebola (2018) have argued, the financial models of the current distributed land by the government are failing to achieve the model of land allocation. The existing policies must be amended and provides for protection of the rights of the South African citizens. The South African Human Rights Commission (SAHRC) also warned that if the Expropriation Bill B4-2015 is passed in its current form, people with traditional land use rights particularly those in former homeland areas as well as farmers who own their farming land, could see their assets and land being expropriated by the government for the purposes of developments and other state use. Furthermore, the SAHRC is concerned that if the Bill is passed, more and more land will become vested in the government and this will disempower people by making them more dependent on the government, and is likely to create economic challenges, by further entrenching poverty and inequality. Hence, it is argued that land expropriation without compensation in South Africa is likely to threaten food security. On other hand Sebola \& Mamabolo (2018) have argued that the reality of the land benefit from the South African local communities through land models is not workable. Accordingly, land redistribution in the country was mainly designed to create a new class of black commercial farmers who would inherit existing white commercial farms (Bank \& Hart, 2018). However, due to incapacity by black beneficiaries the government find itself having to control existing commercial farms on behalf of the beneficiaries. It can be argued that such action taken by government shows lack of capacity by identified South African black landowners. The benefits options and how will the government ensure fairness and sustainability of the affected beneficiaries remain likely impossible.

\section{Land expropriation and food security in south africa}

Land expropriation without compensation continue to be a controversial topic for discussion in the South African political discussion (Kabamba, 2018) and which caught a global attention. Few political rhetorics are concerned about how such expropriation will threaten food security in the country, while the majority are concerned about the achievement of redistributive justice from the process. It has been widely acknowledged that food security is not only a South African problem but also remain a global challenge (du Toit, 2011) which has affected many African countries to extent that charity organisations 
have to intervene. South Africa if affected is likely to be worse since most neighbouring countries are dependent on its fair stable political and agricultural economies. Evidently, not only the commercial agriculture does contribute to food security in the country, but also small-scale farmers do contribute to agricultural production in the country (Altman, Hart \& Jacobs, 2009). Despite agricultural production from both the commercial and small-scale farming, the increasing number of food insecurity remains a critical challenge (Abdu-Raheem \& Worth, 2011). While food security in the country is not in abundance with new models of land management in the country which are not been able to change the status quo. The Human Science Research Council (HSRC) (2011) indicated that almost half of the South African citizens still do not have enough access to regular food. Food security includes the natural aspects of food which include accessibility, availability, utilisation, and stability (Takavarasha, 2016). To date existing literature, indicate that the country is still battling to solve all aspects associated with food security crisis, however, the President of the country have always cautioned everyone that in taking such steps the government will take care that food security is not threatened. It is, however, notable that in the said caution, no clarity was given as to how that surety will be done. Despite that, in South Africa, the land redistribution process had already created avenues for food shortages. As articulated by Sebola \& Tsheola (2014), numerous economically active farms had collapsed immediately after being handed to African beneficiaries for use Although such happened there is only little effort which the government did to resolve such a challenge. Instead, they worsen the situation by attempting to change the constitutional provisions as a way of resolving the problem.

Notably, Land reform cannot be achieved without considering its future effect on food security. Such a political neglect can cause a hilarious economic disaster. Moreover, land reform projects are likely to be handled better in a corrupt free environment. South Africa's corruption level had in the recent past reached a pick level where almost all state parastatals have economically collapsed. Hence leading to Jacob Zuma being recalled from his Presidential seat prior to its expiry. Lane expropriation without compensation and food security are inseparable in economic context and cannot be discussed or implemented separately from each other. The two are indeed concepts of mutual implications. Even if restorative justice is important but achieving it without looking at the economic disaster it would cause would not show much wisdom from country governors. The Government of the Republic of South Africa self-admitted that $90 \%$ of the farms bought for land reform purposes are lying fallow with a total of over 4 000 farms. With this taking place continually and the 4000 farms are increased substantially with the new ones being redistributed, South Africa will not have enough production to live from in future. Sebola (2014) also complained about the African emerging farmers failing to use restituted farms to promote sustainable tourism.

The current state of affairs with land reform in South Africa, especially where farms were given to African beneficiaries through land restitution, there is no guarantee for food security (Grain SA, 2018). Indeed, evidence showed a decline in farm production and the potential threats for food security in many aspects. Evidently there is no time in South Africa where agricultural production ever threatened food security than now. This shows that land use plays a major role in promoting food security through agricultural production. Accordingly, when the government started the land reform programme the believe was that redistribution of farmland, together with other rural development programs, can make a significant contribution to poverty alleviation (Amusan \& Kgotleng, 2015). However, the progress had been argued to be very slow with little success on the restored or redistributed land by government to South African beneficiaries (Bennett, 2013; Sebola \& Tsheola, 2014; Amusan, Kgotleng, 2015; Khoza, 2016). With the recent government agenda on land expropriation without compensation, it can be argued to be the beginning of the end to sustainable economic growth, wealth and prosperity for South African through agricultural production. Sebola \& Tsheola (2014) have argued that no political justification can be achieved without economic considerations of the land restituted or redistributed to individuals for benefit.

\section{The impact of land expropriation on economic activities in restituted farms}

There are different approaches of land use that are argued to be more influential on the productivity of land in the South Africa. Farms achieved by South African Communal Property Associations through land reform have a variety of economic activities such as Livestock farming, Field crops, Game farming, 
Citrus and a combination of livestock and other activities (Department of Rural Development and Land Reform, 2015:19). These economic activities are considered the most contributor to the Gross Domestic Product (GDP) in the country. Contrary to that, Pringle (2013:39) asserts that South Africa has 12, 6\% of dry land crop production with only $4 \%$ of high potential land, while the remaining percentages account for livestock and game farming. Notably, Mmbwengwa, Nyhondo, Myeki, Ngethu \& Schalkwyk (2015) emphasis that the economic contribution of communal farming remains relatively unknown.

Notably, the majority of South African citizens particularly those who reside in rural areas, depend on farming as their major sources of income (Wiggins, 2016:). On the other hand, most community members depend on agricultural produce from different communal farms as their nearby fresh produce market. The agricultural sector in the county is one of the largest industries that contribute to the increased level of job creation (Benhin, 2008; Hachigonta et al. 2013 in Ransom, 2015; den Hartigh, 2016). The sector has created 876000 jobs in the first quarter of 2016, which is an increase of $2 \%$ from the previous quarter but down by $2 \%$ from the same period last year (den Hartigh, 2016). Arguably, the commercial sector is comprised of 46000 commercial farmers with $86 \%$ of agricultural land with small scale communal farmers who owns only $14 \%$ of land in the country (Ortmann, 2005; Sebola \& Tsheola, 2014). This explains that all farms in the country contribute to the society's job creation through different economic activities in farming. Many farms in the country have a variety of economic activities for practising agricultural activities. Notably, all available farms in the country are likely to have certain economic potential which differs from one another. Agricultural production such as livestock, crop produce, game lodging and citrus (Mahanjana \& Cronje, 2000; Bennette, Ainslie \& Davis; Mmbengwa, et.al 2015;) have been argued to be more influential on the productivity of land in the country and are also considered the most the contributing factor to the country's Domestic Product (GDP). However, there is doubt that support for other farmers particularly small-scale farmers can also contribute to the agricultural sector market (Mkhabela, 2018). To date these are the most common farming systems that promote sustainable development. This also promote an opportunity for communal farms to be in the market produce and provide food security to South Africa's population (Mmbengwana et.al, 2015). However, not all economic activities in communal farms are found to be economically viable. Arguably, if the government provide support to the economic activities found ion the restituted land, economic viability in communal farms is likely to improve.

\section{Conclusion and recommendations}

The paper evaluated the land expropriation model and its effect on food security in South Africa. The paper took its perspective from the announcement by President Cyril Ramaphosa two years ago that South Africa will adopt the land expropriation without compensation approach in dealing with land ownership inequality in the country. The paper argued about the concern on how that will be implemented while acknowledging both the political and academic debates that surrounded the issue. South Africa's land issue has been topical for many decades and with little progress achieved in resolving the identified problem. Our land issue had even been an issue of concern that attracted criticism from the Western powers. This paper used a conceptual approach, and it used literature to argue that land expropriation without compensation will threaten food security in South Africa. The paper concludes that land expropriation without compensation that will not consider threat to food security will not achieve intended justice for the people it intends to serve in the country. The paper therefore recommended the following:

The country should consider the economic impact before restorative justice and find a striking balance to benefit both the country and its citizens

The country to resolve land issue problems by balancing the economic imperatives and restorative justice.

The country to adopt a feasible redistributive and restoration plan to benefit both the economy and the citizens

The country should consider food security as of primary importance before adopting any land reform programme

Reviewing the Capacity models used for holders of already restituted and redistributed farms 


\section{References}

Abdu-Raheem, K.A., \& Worth, S.H. (2011). Household food security in South Africa: evaluating extension's paradigms relative to the current food security and development goals. S. Afr. J. Agric. Ext, 39(2): 91-103.

Altman, M, TGB Hart \& P T Jacobs.(2009). Household food security status in South Africa. Agrekon, 48:4, 345361, DOI: $10.1080 / 03031853.2009 .9523831$

Amusan, L., \& Kgotleng, M. (2015). South Africa's Food Security Development Challenges in the Era of Globalisation, Affirmative Action and Land Reform.

Bank, L.J., \& Hart, T.G.B.(2018). How land reform and rural development can help reduce poverty in South Africa. The conversation. University of Cape Town: Cape Town

Bennett, J.E. (2013). Institutions and governance of communal rangelands in South Africa. African Journal of Range $\mathcal{E}$ Forage Science, 30(1\&2):77-83.

Boshoff, T , Sihlobo, W \& Ntombela.(2018). Redistribution of Agricultural Land: Expropriation Without Compensation Debate. Available on ...https://www.researchgate.net > publication > 343290764. Accessed on 19 October 2021

Cousins, B. (2018). Can land reform help reduce poverty and inequality? Institute for poverty, land and agrarian studies (PLAAS), School of Government, University of the Western Cape: Cape Town

Crosby, A. (2021). Land expropriation: 'Farmers alone can't bear burden of addressing apartheid dispossession. Available on https://www.news24.com/news24/southafrica/news/land-expropriation-farmers-alone-cantbear-burden-of-addressing-apartheid-dispossession-20210325. Accessed on 100 October 2021

Du Toit, A. (2011). Comment on the newly released Green Paper on Land Reform, September 26, 2011. Programme for Land and Agrarian Studies (PLAAS), School of Government, University of the Western Cape, Cape Town, South Africa

Gladwin, C. (2017). Expropriation Without Compensation? Schindlers Attorneys - http://www.schindlers.co.za (Accessed: May 14, 2018).

Grain, SA. (2018). Land Reform and Food Security. Grain SA Communications: Pretoria

Head, T. (2018). Land expropriation and land reform: What's the difference? Available on https://www.thesouthafrican.com/news/what-is-land-expropriation-land-reform/. Accessed on 19 October 2021

Khoza, A. (2016). Do not Give Back your Land to White Farmers, KZN Premier. http://www.news24.com/SouthAfrica/News/do-not-give-back-your-land-to-white-farmers-kzn-premier20160225 (Accessed on 19 October 2021)

Kabamba, P. (2018). The effect of land expropriation without compensation on your business. Available on https://www.rsm.global/southafrica/news/effect-land-expropriation-without-compensation-your-business. Accessed on 19 October 2021

Kilian, A. (2018). Unpacking the ANC resolution on land expropriation without compensation at a seminar, in Pretoria, he said land expropriation should not be seen as a destructive measure, but rather as a developmental measure. Available on https://www.engineeringnews.co.za/article/land-expropriation-without-compensationkey-for-economic-growth-masonda-2018-03-06. Accessed on 19 October 2021

Land Audit Report. (2017). Phase 11. Private Land Ownership by Race, Gender and Nationality. Department of Rural Development and Land Reform: Pretoria

Maimane, M. (2018). DA has proud record on land reform, and we reject land expropriation without compensation. Available https://www.google.co.za/search?q=Maimane\%2C+M.+2018.+DA+has+proud+record+on+land+reform\%2C+a nd+we+reject+land+expropriation+without+compensation.\&ei=zbRuYZihLdCPhbIP8KyQgAM\&ved=0ahUK. Accessed on 19 October 2021

Mahanjana, AM \& P.B., Cronje. (2000). Factors affecting goat production in a communal farming system in the Eastern Cape region of South Africa. South African Journal of Animal Science. 30. 149-154. 10.4314/sajas.v30i2.3864.

Mmbengwa, V., Nyondo, L., Ngethu, X. and Van Schalkwyk, H. (2015). Communal livestock farming in South Africa: Does this farming system create jobs for poverty stricken rural areas? Sylwan, 159(10):176-192

Mkhabela, T. (2018). Dual moral hazzard and adverse selection in South African agri-businesses: It takes two to tango. International Food and Agri-business Management Review, 21 (1030):391-406

Sebola, MP. (2014). Sustaining tourism in South African game farms: the benefits of ownership of restituted land by African communities. Sustainable Tourism VI, (187):16-26. doi:10.2495/ST140021

Sebola. M.P \& J.P. Tsheola .(2014). Economics of Agricultural Land Restitution and Redistribution in South Africa: Willing-Seller, Willing-Buyer Business Imperatives Versus Socio-political Transformation? Journal of Human Ecology, 46:2, 113-123, DOI: 10.1080/09709274.2014.11906712 
MA Mamabolo \& MP Sebola. (2018). The engagement of beneficiaries in farm governance of restituted land through the Communal Property Association Model : the ideal versus the reality of beneficiary farms in South Africa. Commonwealth Youth and Development Journal ,16 (2): 1-19

MP Sebola. (2018). Financing emerging black farmers for agricultural development in South Africa: A wasteful and unworkable model for creating black farmers. The Journal for Transdisciplinary Research Southern Africa. 14(1): 1-10

Takavarasha, T. (2016). Issues of food security in South Africa and FAO's role in eradication of food insecurity and malnutrition. Pulses and Food Security Discussion Forum: Kempton Park 